A N N A LES

UNIVERSITATIS MARIAE CURIE-SKŁODOWSKA LUBLIN - POLONIA

VOL. XXX, 1 SECTIO J

Uniwersytet Marii Curie-Skłodowskiej w Lublinie. Wydział Pedagogiki i Psychologii

\title{
JOANNA PLUTA
}

joanna.pluta@umcs.pl

\section{Przemiana bohatera jako przyklad prezentowania duchowości w filmie. Analiza psychologiczna}

\section{Spiritual Transformation of a Character as an Example of Representing}

Spirituality in Film. The Psychological Analysis

\section{STRESZCZENIE}

Artykuł jest próbą pokazania różnych sposobów prezentowania duchowości w filmie. Opracowanie zawiera przegląd wybranych ujęć konstruktu duchowości w psychologii. Główną część stanowi analiza duchowości w trzech filmach amerykańskich (The Green Mile, The Straight Story oraz Into the Wild), z których każdy oferuje nieco inną reprezentację tego pojęcia. The Green Mile odwołuje się do uniwersalnych problemów egzystencjalnych, duchowość zaś przedstawia w postaci bezpośrednich ingerencji siły wyższej. The Straight Story nawiązuje do duchowości, opowiadając „prostą" historię starszego człowieka walczącego ze swoimi słabościami i przeszłymi błędami, co pozwala mu na redefinicję własnej tożsamości. Into the Wild, również bazując na prawdziwej historii, tym razem młodego człowieka, przedstawia bunt przeciwko materializmowi i konsumpcjonizmowi współczesnego świata oraz jego podróż, odbywającą się zarówno w wymiarze fizycznym, jak i duchowym. Artykuł zawiera także analizę przemian duchowych bohaterów poszczególnych filmów.

Słowa kluczowe: duchowość; psychologia; film; przemiana duchowa

\section{WPROWADZENIE. PSYCHOLOGICZNE ROZWAŻANIA NAD DUCHOWOŚCIĄ}

Duchowość wciąż jest uznawana za kontrowersyjny temat badań psychologicznych, a jej zdefiniowanie sprawia badaczom wiele problemów. Jest ona oceniana jako pojęcie bardzo rozmyte, które może być badane tylko przy wykorzy- 
staniu metod analizy jakościowej. W ostatnich latach widać jednak wzrastające zainteresowanie duchowością, które zdaniem Paska jest rezultatem „sytuowania przez współczesnego człowieka poza obszarem religijnym tych celów swojego życia, które dawniej umieszczał on w wyobrażeniach religijnych" (Pasek 2008, s. 1). Istotne znaczenie duchowości podkreśla American Psychological Association, uznając ją za jeden z pięciu filarów dobrostanu (Socha 2000).

Przegląd literatury pozwala wyróżnić wiele sposobów definiowania duchowości, które można pogrupować w pewne kategorie. Duchowość może być rozumiana zgodnie z tradycyjnym ujęciem tego konstruktu jako „synonim religijności” (Socha 2014) bądź pobożność lub sfera mistyki (Pasek 2008), a także szerzej jako doświadczanie świętości - sacrum. Wiele definicji duchowości odnosi się również do pojęcia transcendencji, a więc do pokonywania ograniczeń materialnego świata. To ujęcie widoczne jest u takich badaczy, jak: Kłoczowski (2006; duchowość, jego zdaniem, widoczna jest wszędzie tam, gdzie człowiek przekracza determinizmy przyrody i historii), Pasek (2008; postrzega on duchowość jako pojęcie wiążące się z ,przeciwstawieniem się materialnemu i cielesnemu wymiarowi życia”) oraz Blizek (2013, s. 107; duchowość jest tym, „co nie jest widoczne i wyjaśnialne w odniesieniu do materialnego świata"). Duchowość może być rozumiana ponadto jako „społecznie i kulturowo ustrukturowany proces radzenia sobie z sytuacją egzystencjalną" (Socha 2001, s. 277), np. z ograniczeniami jednostki. Dokładną charakterystykę historii duchowości rozumianej w sposób tradycyjny, chrześcijański, można poznać dzięki książce Aumanna Zarys historii duchowości (2007), zaś o duchowości rozumianej w sposób ateistyczny oraz o zbliżonych pojęciach pisze Comte-Sponville (2011) w publikacji Duchowość ateistyczna.

Duchowość jest odrębna od świata materialnego, ponadczasowa i znajdująca się poza poznaniem zmysłowym (Straś-Romanowska 2011). Do tej pory, w ujęciu chrześcijańskim, stanowiła synonim religijności lub mogła oznaczać „pogłębione życie wewnętrzne” (Pasek 2008, s. 4). Pierwotne znaczenie słowa „duchowość" jest dość bliskie pojęciu pobożności (Pasek 2008, s. 4). Wielu autorów uważa, że religia i duchowość pojmowana w religijny sposób zostały w znacznej mierze zastąpione w XX w. przez psychologię, która zaczęła pełnić ich dotychczasowe funkcje (Pasek 2008). Według Paska (2008) popularność terminu „duchowość" jest ilustracją przemian zachodzących w ostatnich dekadach w kulturze zachodniej. W badaniach nad duchowością często dokonuje się także podziału na duchowość tradycyjną (integralną z religijnym doświadczeniem) oraz nową duchowość (oderwaną od tradycji i religii). Religijność można z kolei zdefiniować jako ,indywidualne ustosunkowanie się człowieka wobec Boga” (Golan 2006, s. 72). Zgodnie z ujęciem substancjalnym można rozumieć ją jako wszystkie przeżycia, zachowania lub myślenie zawierające w sobie coś ponadludzkiego i ponadświatowego (Grom 2009). Jest ona relacją zwrotną między człowiekiem 
i sacrum ${ }^{1}$ (Szymołon 2006). Według Groma (2009; Machoń 2009) religijność jest zjawiskiem posiadającym różne formy. Jej przejawem jest różnorodność motywów wewnętrznych, zrównoważonych lub zaburzonych emocji i odmiennych stanów świadomości. Ponadto może być równoznaczna z duchowością, choć najczęściej drugie z tych pojęć wykorzystuje się do podkreślenia osobowego, indywidualnego aspektu bycia wierzącym. Duchowość według Groma (2009) nie musi dotyczyć transcendencji, ponieważ może odnosić się np. do poszukiwania sensu życia (nie musi on być związany z rzeczywistością ponadludzką).

Odróżniając wspomniane pojęcia, warto zaznaczyć, że religijności często przypisuje się charakter instytucjonalny, a duchowości - osobisty (Socha 2000). Religijność można rozumieć jako jedną z możliwych ekspresji duchowości. Przejawem duchowości jest również tęsknota za przeżyciami wyższego rzędu, chęć stania się lepszym lub kontaktu z czymś wyższym (Socha 2000). Socha wymienia następujące dziedziny duchowości: świadomość i samoświadomość, mądrość, uczucia, wrażliwość, moralność, twórczość, poczucie estetyczne, światopogląd, religijność i wiara. Wiara jest rozumiana jako uniwersalna właściwość ludzi, pozwalająca na tworzenie systemów sensów; wypływa ona z zaangażowania jednostki w centra nadrzędnej wartości, nadaje znaczenie życiu. Jest ona także relacyjna (Socha 2000). Poza tym podtrzymuje ludzi w okresach trudności, pomaga poradzić sobie z licznymi tajemnicami ludzkiego życia (Socha 2000). Jest poszukiwaniem sensu i transgresji (Socha 2000). Może być interpretowana nie tylko w odniesieniu do religii, choć Wojtasik charakteryuje ją jako „szczególny rodzaj zjednoczenia człowieka z Bogiem" (Wojtasik 2006, s. 344). Wiara jest również rozumiana jako wysiłek podejmowany przez jednostkę, aby przyjmować coś za prawdę (Socha 2000).

Jedną ze związanych z religijnością dyscyplin naukowych jest psychologia religii, która „opisuje, (...) wyjaśnia i prognozuje faktyczne przeżycia religijne, poznanie religijne i religijne zachowania" (Grom 2009, s. 27). Zajmuje się ona wyłącznie subiektywną stroną religijności, nie może być natomiast wykorzystywana jako krytyka określonego światopoglądu religijnego (nie zajmuje się tym, czy rzeczywistość transcendentna faktycznie istnieje) (Grom 2009, s. 27; Głaz [red.] 2006). Psychologia religii określa, w jaki sposób różne nastawienia religijne oddziałują na dobrostan. Charakteryzuje również genezę, strukturę i funkcję religijnych przekonań, zachowań i postaw (Szymołon 2006).

Omawiając duchowość w psychologii, wielu autorów pisze o przemianie duchowej. Jest ona rozumiana jako uzyskanie poczucia sensu lub, ze strony subiektywnej, poczucia świętości (Socha 2014).

${ }^{1}$ Sacrum z kolei jest „czymś wyższym”, pozwala człowiekowi przekroczyć doczesność (Szymołon 2006). 
Przemiana duchowa spełnia poniższe warunki (Socha 2014):

- jednostka pokonuje postrzegane przez siebie ograniczenia w czasie, przestrzeni, sferze kontaktów międzyludzkich i obrębie własnych cech,

- przemiana zachodząca na poziomie świadomym jest wynikiem przyjęcia określonych wzorców kulturowych,

- przemiany duchowe nie wiążą się tylko i wyłącznie z zasobami tradycji religijnych,

- przemiana o charakterze nieświadomym jest zwykle związana z poczuciem tajemnicy, zaś swój wyraz znajduje w automatyzmach, zachowaniach rytualnych i sprowokowanych sugestią lub substancjami psychoaktywnymi,

- przemiany mogą być rozumiane jako „radzenie sobie z surowymi treściami doświadczeń wewnętrznych, które nie poddają się poznawczym procesom odkodowania" (Socha 2014, s. 16),

- jeśli niekompetencja w kwestii kodów powoduje lęk lub zaburzenia adaptacyjne, to jedynym rozwiązaniem jest próba nauczenia się tych kodów,

- przemiana wiąże się z pozaracjonalnym poznaniem świata.

Istotą przemiany duchowej jest restrukturyzacja poznawcza dzięki wykorzystaniu zasobów kultury, co zwiększa adaptacyjną elastyczność podmiotu. Duchowość jako przemiana podlega psychologicznym prawidłowościom rozwoju i obejmuje także „szczytowe osiągnięcia ludzkiego ducha” (Socha 2014). Wiąże się ona ze „Zwrotnym punktem w procesie radzenia sobie z sytuacjami egzystencjalnymi" (Socha 2014, s. 12). Podmiot kreuje nowy sens, nową hierarchię wartości lub nowy obraz pewnego fragmentu rzeczywistości. Przemiany duchowe następują w ściśle określonych przypadkach: w granicznej sytuacji egzystencjalnej (takiej jak świadomość śmierci lub przemijania), gdy jednostka zdaje sobie sprawę z ograniczeń o charakterze mniej ostatecznym niż śmierć, oraz podczas koncentracji na działaniach transgresyjnych.

Zagadnieniem związanym z przemianą duchową jest rozwój wiary. Ważny jest tu zarówno aspekt formalny, jak i treściowy (Socha 2000). Rozwój wiary przebiega zgodnie z kategoriami stadialności (inspirowanymi teoriami Eriksona, Piageta, Kohlberga) oraz prymatu struktury nad treścią. Stadia wyróżnione przez Fowlera (1981 za: Socha 2000) to: prestadium wiary niezróżnicowanej, wiara intuicyjno-projekcyjna, wiara mityczno-literacka, wiara syntetyczno-konwencjonalna, wiara indywidualno-refleksyjna, wiara koniunktywna, wiara uniwersalizująca. 


\section{DUCHOWOŚĆ W UJĘCIU PSYCHOLOGICZNYM A FILMY. WPROWADZENIE DO PROBLEMATYKI DUCHOWOŚCI W FILMIE}

Obecnie znaczna część społeczeństwa doświadcza duchowości i religii przez filmy, w związku z czym poznanie sposobów, w jaki media przedstawiają duchowość, jest niezbędne, aby zrozumieć, jak współczesne społeczeństwa ją pojmują (Blizek 2013). Zdaniem Blizka w filmach można wyróżnić dwa rodzaje duchowości: „real” spirituality - „prawdziwą” duchowość (filmy, które intencjonalnie zawierają duchowość będącą wynikiem świadomych działań reżysera i innych twórców filmu) oraz „,reel” spirituality, rozumianą jako duchowość „przypadkowa”, której widzowie doświadczają podczas oglądania pomimo tego, że zawarcie tej tematyki nie było celem twórców filmu (czasem może być konsekwencją produkowania filmów w ,hollywoodzki” sposób).

Filmy mogą przedstawiać albo tylko religię, albo tylko duchowość lub oba zagadnienia. Religia w perspektywie filmoznawczej jest definiowana przez jej związek z instytucją, organizacją bądź hierarchią autorytetów, z konkretnymi rytuałami, zbiorem doktryn i zbiorem reguł kierujących zachowaniem wiernych. Duchowość z kolei można postrzegać jako zainteresowanie jednostkową, duchową wolnością, mistycznym doświadczeniem, medytacją, docenieniem wszystkich religii i wiarą w uniwersalne braterstwo ludzi (i inne wartości wyższe) (Blizek 2013).

Sygnałem obecności problematyki duchowości w filmach jest występowanie: inspiracji, wybaczenia, nadziei, sprawiedliwości, odwagi, odrodzenia się (zbawienia), miłości pojmowanej w sposób duchowy oraz przemiany bohatera (Blizek 2013). O duchowości świadczą także reprezentacje bohaterów korzystających ze swoich własnych duchowych zasobów, aby pokonywać trudności, oraz postaci kształtujące swoją tożsamość na bazie określonych elementów kulturowych lub poszukujące swojej tożsamości (Rossister 1999). O duchowości mogą mówić również filmy zawierające przedstawienie pustki egzystencjalnej oraz poczucia osamotnienia (Straś-Romanowska 2011). Zdaniem Blizka (2013) duchowość jest czymś, czego widz podczas oglądania filmu powinien doświadczyć. Oglądając imponującą przemianę bohatera bądź niezwykłe przykłady odwagi, widz powinien sam czuć się zainspirowany, aby dokonać pewnych zmian w swoim życiu.

Jako możliwe do zaobserwowania przejawy życia duchowego Straś-Romanowska wymienia: „(...) świadomość i samoświadomość, otwartość poznawczą, wolność wewnętrzną, poszukiwanie sensu życia, uczuciowość wyższą, dążenie do samorealizacji, zdolność przezwyciężania własnych ograniczeń, intencjonalność prospołeczną, mądrość" (Straś-Romanowska 2011, s. 151). Autorka mówi też o innych przykładach duchowości w życiu codziennym, jak: rozmyślanie nad danym zachowaniem w świetle wartości moralnych i religijnych, przeżywanie różnych wątpliwości i dylematów, odczuwanie wdzięczności bądź 
dezaprobaty wobec spostrzeżonego zła oraz rozmyślanie o sensie życia (Straś-Romanowska 2011, s. 151). Wymienione przykłady życia duchowego są możliwe do prześledzenia w filmach.

Mimo obszernej literatury na temat różnych sposobów rozumienia duchowości badania nad tym zagadnieniem w filmach są mniej liczne, lecz kilka z nich zostanie wskazanych w niniejszym artykule. Blizek (2013) analizuje przykłady filmów, opisując duchowość w filmie Priest (1994), który zdaniem autora porusza problematykę zarówno duchowości, jak i religijności. Badacz charakteryzuje również Lot nad kukutczym gniazdem (1975), dokonując porównania historii McMurphy'ego z historią ukrzyżowania Chrystusa. Pak-Shiraz, autorka książki Sh'i Islam in Iranian Cinema, dokonała z kolei prześledzenia religii i duchowości w irańskich filmach. Analizując kwestię ,uczuć narodowych” w filmach, opisała stworzenie sekcji na Fajr Film Festival, która nazywa się ,,sinema-i ma’nagri” (kino duchowe); scharakteryzowała także filmy przedstawiające duchowieństwo oraz sposoby prezentowania moralnych wartości. Badaczka podkreśliła, że kino może wzmacniać religię (Matti 2012). Z kolei Rossister (1999) zbadał kształtujący wpływ filmów i telewizji na duchowość dzieci. Założył on, że filmy mają moralny i duchowy wpływ oraz stanowią materiał źródłowy, na podstawie którego młodzież może budować swoją tożsamość. Ponadto nawołuje on wychowawców i pedagogów do zgłębiania problematyki duchowego i moralnego oddziaływania mediów.

Spośród polskich badań nad filmem warto wymienić kilka prac, które powstały nie tylko w ciągu ostatnich kilku lat. Już w 1982 r. Jan Białostocki (2008) wydał esej, który stanowi analizę symboliki i kompozycji w filmie Formana z 1975 r. Lot nad kukutczym gniazdem. Autor podkreślił znaczenie zjawisk zachodzących w psychice osób żyjących w szpitalu psychiatrycznym, stanowiącym „świat zamknięty”; zwrócił także uwagę na zrównoważenie idei i rzeczywistości we wspomnianym tekście kultury. Białostocki (2008) zaakcentował wartość filmu przedstawiającego szpital psychiatryczny jako metafory systemu totalitarnego. Wspomniał również jeden z głównych tematów dzieła - trudną do ustalenia granicę między patologią a normalnością. W omawianym eseju zaznaczone są ponadto problemy związane $\mathrm{z}$ funkcjonowaniem jednostki w grupie oraz $\mathrm{z}$ wzajemnym wpływem bohaterów, ich współzależnością. Ważne jest zwrócenie uwagi na zbawczą moc McMurphy’ego, który wyrywa innych pacjentów z letargu i motywuje ich do zmiany.

Problemowi przedstawiania sfery sacrum w kinie została poświęcona książka Poszukiwanie i degradowanie sacrum w kinie, która stanowi zbiór artykułów pod redakcją Przylipiaka i Kornackiego (2002). Praca została podzielona na dwie części - pierwsza opowiada o śledzeniu w kinie duchowości pojmowanej w religijny, chrześcijański sposób, zaś druga mówi o „zdesekralizowanym” świecie, w którym dokonuje się kontestacji sacrum w jego tradycyjnym ujęciu. Redak- 
torzy we wstępie zaznaczają, że w pewnym okresie kino, ze względu na bycie uzależnionym od pokazywania tylko „tego, co widoczne”, było uważane za skazane na „immanentną laickość” (Przylipiak, Kornacki [red.] 2002, s. 7). Przylipiak i Kornacki podkreślają także, że filmy, przedstawiając pewne spojrzenie na duchowość, zarazem ją promują. Podobnie jak inni badacze, autorzy zwracają uwagę na zależność przemian dokonujących się w kinie duchowym od przemian w życiu społecznym. Książka przedstawia liczne formy, jakie może przyjąć sacrum i duchowość w kinie.

Nawiązaniem do poprzedniej pozycji jest książka pt. Sacrum w kinie - dekadę później pod redakcją Konefała, Kornackiego i Zelent (2013). Praca ta również jest zbiorem artykułów pisanych z perspektywy filmoznawczej, odnoszących się do tematyki duchowości i sacrum oraz przemian, jakie dokonały się w kinie. Znaczna większość opracowań odnosi się do chrześcijańskiego rozumienia religijności. Ponadto artykuły zawierają rozważania teoretyczne nad związkami kina $\mathrm{z}$ duchowością, próby interpretacji degradowania symboli religijnych w mediach, a także refleksje dotyczące religijności ateistycznej.

W 2013 r. ukazała się również książka Waligórskiej-Olejniczak Sacrum $w$ drodze. Dzieło to jest $\mathrm{w}$ znacznej mierze inspirowane nurtem postmodernistycznym, a jego celem było dokonanie filmoznawczej interpretacji Pulp Fiction Quentina Tarantino oraz prozy poetyckiej Moskwa-Pietuszki Jerofiejewa. Problematykę duchowości porusza też Burski (2005), który pisze o ciągle zwiększającym się wpływie mediów na normy, mentalność, duchowość i styl życia społeczeństw. Autor pojmuje duchowość jako fenomen związany z komunikacją. Celem mediów, jego zdaniem, jest formacja człowieka. Podkreśla przy tym, że media mogą stać się nośnikami łaski bożej.

\section{ANALIZA SPOSOBÓW PRZEDSTAWIENIA DUCHOWOŚCI W WYBRANYCH FILMACH AMERYKAŃSKICH}

\section{The Green Mile (1999)}

Dramat z 1999 r. pt. The Green Mile (Zielona mila) jest znakomita adaptacją prozy Stephena Kinga w reżyserii Franka Darabonta. Został on wyróżniony wieloma nagrodami i nominacjami. Dzieło to do zagadnienia duchowości odnosi się w sposób wielopłaszczyznowy. Głównym bohaterem jest strażnik więzienny, Paul Edgecomb, który z perspektywy swojej starości analizuje jedno z najbardziej zaskakujących zdarzeń w swoim życiu. Przypomina sobie, jak w latach 30 . pracował w bloku śmierci w jednym $\mathrm{z}$ amerykańskich więzień oraz jak poznał tam wielkiego, czarnoskórego więźnia, Johna Coffeya, który został niesłusznie skazany na śmierć za gwałt i zabicie dwóch białych dziewczynek. 
Przejawy duchowości można charakteryzować w odniesieniu do poszczególnych postaci oraz analizując samą fabułę filmu. Widoczny jest tu również motyw przemiany głównego bohatera. Dzieło Darabonta porusza jeden z bardzo istotnych dylematów współczesnych społeczeństw dotyczący słuszności kary śmierci oraz mówiący o tym, czy człowiek ma prawo w imię sprawiedliwości zabić drugiego człowieka.

Film umożliwia widzowi dogłębne poznanie poszczególnych postaci, bardzo często wraz z ich rozterkami i wątpliwościami. Wart zauważenia jest fakt, że mimo okrutnego zawodu, który wykonuje Paul oraz pozostali strażnicy, większość z nich podchodzi z szacunkiem i wsparciem do więźniów. Nie nadużywają przemocy, próbują pocieszać niektórych skazanych i starają się im pomóc przebrnąć przez ostatnie chwile przed śmiercią. Strategią radzenia sobie z sytuacją śmierci jest tutaj w znacznej mierze humor. Zachowanie strażników pokazuje, że każdy człowiek, niezależnie od popełnionej zbrodni, zasługuje na wsparcie i godne traktowanie.

Zielona mila zawiera też pewne bezpośrednie przejawy duchowości, które można uznać za dosłowną manifestację bądź ingerencję sfery sacrum. Można tutaj wskazać głównie uzdrowienia dokonywane przez Johna Coffeya. W filmie wszystkie sytuacje związane z manifestacją duchowości w postaci „cudu”, np. z uzdrowieniem któregoś z bohaterów przez Coffeya, są ukazywane wraz z niewytłumaczalnymi zjawiskami (jak np. gaśnięcie świateł, wstrząsy ziemi i budyn$\mathrm{ku}$ ). Jest to symbol świadczący o mistycyzmie pokazywanych zdarzeń. John Coffey, w rezultacie swoich dokonań, zostaje uznany za „,cud od Boga”. Dodatkowym efektem jego uzdrowień jest niezwykłe przedłużenie życia, którego doświadcza m.in. Paul. Duchowość w przypadku Coffeya manifestuje się również w jego mistycznej zdolności do współodczuwania oraz zaglądania w myśli i dusze innych bohaterów (rozumienia ich intencji). Paul w momencie opowiadania historii ma 108 lat, zaś jego długowieczność, będąca następstwem cudu Coffeya, jest dla niego w pewnym sensie błogosławieństwem, ale i pokutą za zgodę na przeprowadzenie egzekucji niewinnego człowieka („Każdy ma swoją zieloną...”). Mówiąc o Coffeyu, warto krótko wspomnieć o olbrzymim kontraście między jego pozornie przerażającym wyglądem (olbrzymi wzrost, potężna postura, czarna skóra, zaznaczona muskulatura) a niezwykle łagodnym, wręcz dziecinnym usposobieniem i chęcią pomagania innym. Jego potężny wzrost może nawiązywać do wielkości Boga, podobnie jak zdolność uleczania z chorób, które Coffey najczęściej później ,wydycha” w postaci much ${ }^{2}$ (Laurent 2003). Coffey jest najczęściej postrzegany - zarówno przez większość strażników, jak i widzów - jako uczciwa, wraż-

${ }^{2}$ Laurent (2003) wskazuje na odniesienie much do szatana - Belzebuba. Określenie „Baalzebub” oznacza „władca much”, zaś muchy są symbolem sądu bożego lub zła (co jest nawiązaniem do jednej z plag). 
liwa osoba, bezpośrednio odczuwająca cierpienie innych. Deklaruje on, że męczy go ból obecny na świecie, sprawiany sobie nawzajem przez ludzi (Brussat, Brussat 1995; Laurent 2003).

Nie mniej ważną postacią jest główny bohater, Paul, który w trakcie akcji musi zmierzyć się z kilkoma dylematami etycznymi. Pod wpływem wydarzeń dziejących się w bloku śmierci zaczyna kwestionować sensowność kary śmierci, lecz cały czas wykonuje z oddaniem swoją pracę. Ze względu na niezwykłe wsparcie, jakie otrzymał od Coffeya, proponuje więźniowi pomoc w ucieczce. Kiedy jednak Coffey, będąc niewinnym, decyduje się pokornie przyjąć karę śmierci, Paul ostatecznie bierze udział w jego egzekucji i ją przeprowadza. Po tym wydarzeniu przerywa swoją dotychczasową pracę, zaś opowiedziana w filmie historia stanowi jedno z najczęściej nawiedzających go wspomnień w późniejszym życiu. Warto wspomnieć o stosunku do pracy, jaki wykazywał Paul. Był on bardzo obowiązkowy, przedkładał pracę nad własne zdrowie, wykonując obowiązki zawodowe pomimo bardzo złego samopoczucia. Ze znacznym trudem przychodziło mu podejmowanie decyzji o wykroczeniu poza swoje powinności służbowe. Dodatkowo, kiedy okazało się, że Coffey jest niewinny, Paul ostatecznie zdecydował się z trudem wykonać wyrok śmierci, mimo że wiedział, że jest on bezpodstawny. Potrafił również doskonale kontrolować swoje emocje, np. gdy miał do czynienia z nieposłusznym więźniem.

Kolejnym istotnym tematem poruszanym przez film są relacje między białymi i czarnymi. Ebert pisze, że w Zielonej mili zadaniem czarnego człowieka jest wchłanianie bólu białych, przez co daje im ulgę, wybaczenie i zbawienie (Ebert 1999).

Zdaniem Laurent (2003) film ten może być odczytywany jako reinterpretacja męki i śmierci Chrystusa, zaś John Coffey może być uznawany za postać chrystusową̧ ${ }^{3}$ Ma on dostęp do myśli i uczuć innych ludzi, potrafi wchłaniać ich ból, winę i grzechy oraz z nimi cierpieć. W filmie pojawia się też dwóch bohaterów stanowiących reprezentację zła - William „Wild Bill” Wharton, gwałtowny więzień i morderca, oraz „opętany” strażnik uwielbiający okrucieństwo, Percy Wetmore. Zielona mila zawiera dużo odniesień do Boga i jego ingerencji (bądź braku) w przebieg wydarzeń. Symbolem religijności jest tu również łańcuszek ze św. Krzysztofem, który Coffey dostał od uzdrowionej kobiety, mający symbolizować ochronę i opiekę. Zielona mila zawiera zatem nawiązania zarówno do re-

\footnotetext{
${ }^{3}$ Najprostszym nawiązaniem do Jezusa Chrystusa jest użycie takich samych inicjałów (John Coffey - J.C.; Laurent 2003). Tak jak Chrystus, Coffey zostaje niesprawiedliwie osądzony i traci życie w wyniku nieuczciwej kary, podczas gdy wcześniej próbował jedynie pomagać innym (Laurent 2003). Czterej strażnicy, obecni podczas egzekucji niewinnego więźnia, stanowią reprezentację czterech centurionów obecnych przy śmierci Chrystusa. Strażnik Hal Moores, który podpisał akt egzekucji, a którego żonę uratował od śmierci Coffey, może być postrzegany jako Piłat itd.
} 
ligijności, wiary, jak i duchowości ateistycznej, zaś sposób przedstawienia tych zagadnień w filmie czyni go atrakcyjnym dla wielu widzów, z których niektórzy z pewnością doszukają się rozbudowanych metafor.

\section{The Straight Story (1999)}

Nieco inaczej niż w poprzednim filmie duchowość jest przedstawiona w Prostej historii w reżyserii Davida Lyncha. Bohaterowie są tutaj zwykłymi ludźmi, a ich przygodom nie towarzyszą żadne bezpośrednie manifestacje siły nadprzyrodzonej. Można powiedzieć, że film ten „,nadaje narracyjny charakter tematyce teologicznej" przez ujawnianie się Boga w wydarzeniach, obiektach i ludziach (Johnston 2006, s. 109). Akcja tego dzieła jest oparta na prawdziwych wydarzeniach, które miały miejsce w 1994 r. Główny bohater, Alvin Straight, zaczyna cierpieć na liczne objawy cukrzycy, które prowadzą do jego zasłabnięcia. Ze względu na jego wiek (prawie 80 lat) ma również znaczne problemy z poruszaniem się i ze wzrokiem. Bohater nie chce przyznać się do żadnej słabości ani przed sobą, ani przed nikim z bliskich. Tuż po zasłabnięciu dowiaduje się o chorobie swojego brata, który miał udar, i decyduje się na odwiedzenie go przed śmiercią. Aby tego dokonać, musi przebyć odległość ze stanu Iowa do Wisconsin. Jak mówi mu wiele osób, wyzwanie to przekracza jego siły, gdyż nawet nie ma prawa jazdy. Alvin decyduje się jednak na przebycie 240 mil przy użyciu niewielkiego traktorka - prawie trzydziestoletniej kosiarki firmy John Deere. Celem podróży jest zarówno towarzyszenie bratu przy ostatnich chwilach jego życia, jak i pojednanie się z nim przed śmiercią.

Film, ze względu na tematykę, porusza kilka zagadnień związanych z duchowością. Pierwszym jest sposób radzenia sobie w sytuacji choroby oraz śmierci własnej i bliskich. Alvin całkowicie ignoruje zalecenia lekarza, nie przyznaje się do słabości i swojego wieku. Często powtarza, że jest to wynik jego upartości i dumy. Interesujące są też relacje między braćmi. Alvin i Lyle pokłócili się 10 lat temu i od tej pory nie mieli ze sobą kontaktu, aż do momentu, gdy Alvin dostał informację o chorobie brata. Nie skontaktował się z nim wcześniej, natomiast prościej, niż rozpocząć rozmowę po tylu latach, było mu podjąć konkretną akcję - wyruszyć w podróż. Główny bohater porównuje swoje relacje z bratem do biblijnego rodzeństwa: Kaina i Abla.

The Straight Story jest klasycznym filmem drogi, a więc gatunkiem charakterystycznym dla kina amerykańskiego. W filmach reprezentujących ten gatunek droga i podróż są odczytywane jako symbole głębokiej przemiany duchowej głównego bohatera, który przez pozostawienie swojego dotychczasowego życia i zetknięcie się z nowymi wyzwaniami zmienia swój sposób rozumienia świata i odkrywa własną tożsamość. Zwykle takie doświadczenie pozwala bohate- 
rom spojrzeć na swoje życie i problemy z nowej perspektywy. Przemiana, która następuje w Alvinie, ma charakter wieloaspektowy. Droga jest dla niego sposobem uporania się ze swoją trudną przeszłością weterana wojennego oraz byłego alkoholika, a także osoby, która zerwała kontakt z bratem. Dzięki różnym wydarzeniom Alvin uczy się przyznawać do swoich słabości i błędów. W przeżyciu przemiany pomagają mu losowo spotkane osoby, z którymi prowadzi pozornie proste rozmowy, pozwalające mu jednak na redefinicję swojej tożsamości. Te przypadkowe spotkania być może są jedyną okazją, aby wypowiedzieć pewne trudne wspomnienia po raz pierwszy oraz pokonać demony przeszłości i uzyskać oczyszczenie.

Odniesieniem do duchowej sfery są z pewnością szczególne naciski kładzione na ważne elementy z przeszłości Alvina, takie jak jego alkoholizm czy udział w II wojnie światowej (w szczególności fakt, że przez własny błąd zabił żołnierza walczącego po jego stronie). Omawiając duchowość w odniesieniu do postaci centralnej, należy podkreślić, iż posiada ona wszystkie właściwości uznawane za składające się na charakterystyczne dla Ameryki cechy kulturowe i mity. Można tu wymienić indywidualizm bohatera, jego niezależność, samodzielność (z których Alvin za wszelką cenę nie chce zrezygnować - mimo złego stanu zdrowia podejmuje decyzję o podróży, zależy mu na samodzielnym jej ukończeniu) oraz wytrwałość i dumę. Jest on zatem bohaterem w znacznym stopniu uosabiającym amerykański mit. Na podstawie oszczędnych wypowiedzi Alvina można określić jego sposób rozumienia rodziny, którą porównuje do wiązki splecionych gałęzi, której nie da się przełamać. Rodzina ma jednak dla niego kluczowe znaczenie, czego dowodzi jego upór w dążeniu do celu oraz gotowość do poświęceń. W trakcie swojej podróży Alvin zaczyna doskonale rozumieć, że stanowienie rodziny polega na docenianiu wartości wszystkich jej członków, która wynika z faktu, że zostali oni stworzeni na obraz i podobieństwo Boga (Johnston 2011). Dostrzega również wartość bezwarunkowej miłości.

Film zawiera ponadto rozważania dotyczące starzenia się. W omawianym tekście kultury niezwykle silnie jest zaakcentowana istotność determinacji i siły woli, która pozwala podnieść się Alvinowi po upadku oraz przekroczyć własne ograniczenia. Główny bohater dzięki swojemu wiekowi wydaje się posiadać głęboką mądrość życiową, zahartowaną przez doświadczenia niejednokrotnie pełne bólu i rozczarowań oraz przez szacunek i docenienie życia (Johnston 2011). Rozpatrując Alvina w kontekście teorii rozwoju Fowlera (1981 za: Socha 2000), prawdopodobnie możliwe byłoby przypisanie mu posiadania wiary koniunktywnej, a więc umiejętności dostrzegania złożoności życia i relatywności świata. Na koniec warto zaznaczyć, że - zdaniem Wojciechowskiego (2015) - omawiany film ma „siłę biblijnej przypowieści”. Inspiruje także do rozważań nad pytaniami ostatecznymi oraz do wiary w transcendencję i niewyjaśnione zjawiska (Johnston 2006). Refleksjom sprzyja wolne tempo akcji i malownicze, bajkowe krajobrazy. 


\section{Into the Wild (2007)}

Ostatni analizowany film to Into the Wild (Wszystko za życie) w reżyserii Seana Penna. Historia w nim przedstawiona jest oparta na prawdziwych zdarzeniach, które wcześniej stanowiły kanwę dla powieści autorstwa Jona Krakauera (1996). Dzieło opowiada historię życia Christophera, który po ukończeniu studiów decyduje się porzucić zwykłe, stereotypowe życie i wyrusza w nieznane. Jednym z bezpośrednich powodów ucieczki Chrisa od cywilizacji były ciągłe kłótnie jego rodziców i ich nadmierna wiara w znaczenie materialnego dobrobytu. Główny bohater starał się dzięki swojej podróży odnaleźć i odbudować więź z naturą, chciał też uciec - jak sam mówił - od zakłamania współczesnego świata.

Jego podróż obejmuje wiele odległych stanów (jak np. Południowa Dakota, Kalifornia, Alaska), zaś środkiem transportu był głównie autostop i kajak, a także poruszanie się na piechotę. Bohater przeżywa podróż zarówno w przestrzeni, jak i w wymiarze duchowym (Brussat, Brussat 2016). Wybór Chrisa jest w znaczący sposób inspirowany twórczością dziewiętnastowiecznych transcendentalistów, zwłaszcza Henry'ego Davida Thoreau (1817-1862). Chris starał się realizować w swoim codziennym życiu główne założenia tego nurtu. Można do nich zaliczyć: życie blisko natury; skupienie na życiu duchowym; dochodzenie do sukcesu przy pomocy samodzielnej pracy; postrzeganie relacji z Bogiem jako indywidualnej, prywatnej więzi; wiarę w boskość człowieka i braterskość ludzi, w demokrację i indywidualizm; innowacyjność; propagowanie wiary $\mathrm{w}$ siebie i niezależności; poleganie na intuicji (Characteristics...). Próba wdrażania wymienionych wartości i postulatów w codziennym życiu wiązała się z umieszczeniem duchowości w centrum swoich zainteresowań.

Celem podróży Chrisa było dogłębne poznanie swojej tożsamości, zgłębienie sensu życia przez bliski kontakt z naturą i sprawdzenie się w trudnych warunkach. Zakładał, że „serce” ludzkiej duszy buduje się przez własne doświadczenia - to stanowiło podstawę jego podróży. Into the Wild może być postrzegane jako film drogi. Podobnie jak w The Straight Story, Chris przechodzi przemianę pod wpływem osób spotkanych na swojej drodze. Dzięki tym spotkaniom widoczna jest jego transformacja od „Zatroskanego, impulsywnego chłopca” do „odważnego i oddanego duchowego pielgrzyma" (Scott 2007). Symbolem zmian zachodzących w głównym bohaterze jest odrzucenie przez niego starego imienia i zaadoptowanie pseudonimu - Alexander Supertramp. Przyjęcie nowego imienia wskazuje na oczyszczenie i całkowitą separację od poprzedniego życia. Etapy, przez które przechodzi Chris, są zasygnalizowane przez pojawiające się na ekranie napisy (Rozdział I: Moje własne narodzenie, Rozdział II: Wiek dojrzewania, Rozdział III: Wiek męski, Rozdział IV: Rodzina, Rozdział końcowy: Zdobywanie madro- 
ści). Tytuły te stanowią symbol przemian, wskazują także na wartości centralne w danym okresie życia bohatera. Podkreślają ponadto dominującą w filmie metaforę - porównanie podróży do życia.

Widzowie zwykle postrzegają Chrisa jako niezwykłego, utalentowanego młodego mężczyznę, cechującego się odwagą graniczącą z lekkomyślnością, co wraz z innymi czynnikami doprowadza go ostatecznie do tragedii. Bohater czuł silną potrzebę podążania za swoimi ideałami w celu zrealizowania planu „bycia bliżej natury i prawdy". Widoczny jest jego upór, niezależność i niechęć ulegania wpływom. Mimo tego, że w czasie podróży spotkał wiele osób oferujących mu pomoc i nawet stałe zamieszkanie, zawsze pozostawał niezmienne skupiony (,zafiksowany") na swoim ostatecznym celu - dotarciu na Alaskę (Krakauer 1996). Gdy przebywał z innymi ludźmi, był wobec nich otwarty i akceptujący, jednak nie chciał wchodzić w żadne bliskie relacje, obawiał się nadmiernego zaangażowania, nie chciał być zależny od nikogo i niczego. Ograniczał lub próbował całkowicie pozbyć się wszelkich popędów typowo cielesnych, np. seksualnego, gdyż jego zdaniem takie pobudki mogły odciągnąć go od dążenia do transcendencji (Krakauer 1996). Chris cechował się również wysokim poziomem inteligencji, zaradnością, ambicją oraz znajomością literatury i filozofii (Hough 2014). Poszukiwał sensu prawdopodobnie w wyniku doświadczenia skończoności i ograniczoności ludzkiej, które spotkało się z jego akceptacją (Socha 2000). Bliskość natury, odrzucenie materializmu i zdobyczy cywilizacji, życie w prostocie i ciągłe przemieszczanie się było dla niego równoznaczne z obcowaniem ze sferą sacrum. Doświadczenia te pozwalały mu wykraczać poza to, co doczesne (Szymołon 2006). Chęć życia tym, co duchowe, zaprowadziła go do śmierci.

Film zawiera także inne bezpośrednie odniesienia do sfery duchowej człowieka. Przykładem może być scena, w której Chris, przed wyprawą, decyduje się oddać na cele charytatywne prawie wszystko, co posiada. Będąc na początku swojej wyprawy, pali wszystkie swoje pieniądze i niszczy karty kredytowe, odrzucając tym samym wszystko, co materialne. Dzieło ukazuje również wiele relacji międzyludzkich charakteryzujących się bezinteresownością. Przykładem może być pomoc, którą Chris otrzymywał od przypadkowo napotykanych osób. Bohater, dzięki swojej podróży, dowiedział się wiele na temat kluczowych dla niego wartości, sposobów realizacji swoich celów oraz miłości i wybaczenia (Brussat, Brussat 2016). Swoje przemyślenia o tematyce egzystencjalnej zapisał w nigdy niewysłanych listach i notatniku. Jego ostatnia refleksja przed śmiercią brzmi: „Happiness [is] only real when shared”. 


\section{ZAKOŃCZENIE}

Podsumowując, duchowość w filmach może być reprezentowana w sposób bezpośredni (w postaci dosłownych nawiązań do różnie pojmowanych sił nadprzyrodzonych lub do Boga oraz w postaci prostych, popularnych przedstawień życia po śmierci, np. w filmie Duch lub Beetle Juice) lub pośredni. Jednym z bezpośrednich, niewysublimowanych, dosłownych reprezentacji duchowości i religijności w filmie jest ich przedstawienie w dziele Altered States (1980, Odmienne stany świadomości). W obrazie tym główny bohater w wyniku zażywania środków psychotropowych i deprywacji sensorycznej próbuje wniknąć w duchowość człowieka, która przybiera formę omamów wzrokowych, jaskrawych wizji o religijnym lub mistycznym charakterze, których przedstawienie działa na widzów przytłaczająco. W drugim przypadku duchowość uwidacznia się w filmach przez prezentowanie przemian zachodzących w głównym bohaterze oraz pokazywanie jego dylematów życiowych, trudnych decyzji, problemów egzystencjalnych itd. Zagadnienia związane $\mathrm{z}$ duchowością mogą znajdować się $\mathrm{w}$ centrum zainteresowań danego filmu, napędzając jego akcję, lub mogą być swoistym „efektem ubocznym", niezamierzonym pierwotnie przez filmowców. Duchowość we wszystkich wyżej wymienionych filmach jest także czymś, czego widz doświadcza (np. losy bohaterów w The Straight Story lub w Into the Wild mogą stanowić inspirację do przemyśleń dotyczących własnego życia lub do dokonania pewnych zmian).

Nawiązując do podziału Blizka (2013), można powiedzieć, że filmy omówione tutaj cechują się przede wszystkim tzw. ,real” spirituality (mają charakter intencjonalny). Połowa $\mathrm{z}$ przeanalizowanych filmów stanowi również reinterpretację prawdziwych historii, wszystkie zaś są oparte na powieściach. Większość z omówionych filmów dotyczyła przemian bohaterów i ich dążenia do samodoskonalenia się. Widoczne było u nich, powszechne dla wielu ludzi, „dążenie do nadania swemu życiu sensu poprzez coś, co jest poza ja, lecz dla ja" (Socha 2000, s. 167).

Przemiany bohaterów można odnieść do teorii dezintegracji pozytywnej autorstwa Kazimierza Dąbrowskiego. Bohaterowie omówionych filmów, w różny sposób, starali się dążyć do pewnego ideału, do poznania lub zreorganizowania swojej osobowości rozumianej jako „cel i rezultat [...] dezintegracji” (Dąbrowski 1979, s. 1), czyli procesu rozbicia struktury psychicznej. Przez wydarzenia prezentowane w filmach bohaterowie najczęściej uzyskiwali wtórną, wyższą integrację. Odwołując się do koncepcji Fowlera (1981 za: Socha 2000), można stwierdzić, że prawdopodobnie wszyscy bohaterowie charakteryzowali się wiarą znajdującą się w stadium indywidualno-refleksyjnym lub na późniejszych stadiach, a więc posiadali świadomy system wartości oraz zdolność do racjonalnego krytycyzmu i świadomego kierowania własnym rozwojem. 
Przedstawiona analiza filmów może stanowić wstęp do rozważań nad filmowymi reprezentacjami duchowości w ujęciu psychologicznym. Obejmuje ona filmy nawiązujące głównie do duchowości, w mniejszym stopniu do religijności. W przyszłości warto byłoby prześledzić filmy zajmujące się religijnością. Należy z pewnością rozszerzyć i pogłębić spektrum analizy. Interesującym tematem rozważań byłaby również interpretacja filmów, które stawiają pytanie o duchowość jako wyznacznik człowieczeństwa danego bohatera (np. Blade Runner). Na koniec warto zauważyć, że każdego roku powstaje wiele filmów, a znacząca część z nich charakteryzuje się pewnymi odniesieniami do duchowości. Może to wskazywać na fakt, że duchowość stanowi atrakcyjny element fabuły i portretu bohaterów, przez co wpływa na popularność filmu.

\section{BIBLIOGRAFIA}

Aumann J. (2007), Zarys historii duchowości, Kielce: Wydawnictwo „Jedność”.

Białostocki J. (2008), Lot nad kukułczym gniazdem: kompozycja i symbolika, [w:] Wybór pism estetycznych, Kraków: Universitas.

Blizek W.L. (2013), Religion and spirituality in the movies, "International Journal of Religion and Spirituality in Society", No. 2.

Brussat F., Brussat M.A (1995), The Green Mile. Film review, "Spirituality and Practice", www. spiritualityandpractice.com/films/reviews/view/1995 (dostęp: 26.05.2016).

Brussat F., Brussat M.A. (2016), Into the Wild. Film review, "Spirituality and Practice", www.spiritualityandpractice.com/films/reviews/view/17672 (dostęp: 01.05.2016).

Burski K. (2005), Duchowość i media - wzajemne relacje, „Soter”, nr 16(44).

Characteristics of Transcendenta, http://iws.collin.edu/mizell/2327/characteristics_of_transcendenta.htm (dostęp: 01.05.2016).

Comte-Sponville A. (2011), Duchowość ateistyczna, Warszawa: Wydawnictwo Czarna Owca.

Dąbrowski K. (1979), Dezintegracja pozytywna, Warszawa: PIW.

Ebert R. (1999), The Green Mile Movie Review \& Film Summary. Rogerebert.com, www.rogerebert. com/reviews/the-green-mile-1999 (dostęp: 01.05.2016).

Głaz S.G. (red.) (2006), Podstawowe zagadnienia psychologii religii, Kraków: Wydawnictwo WAM.

Golan Z. (2006), Pojęcie religijności, [w:] S.G. Głaz (red.), Podstawowe zagadnienia psychologii religii, Kraków: Wydawnictwo WAM.

Grom B.G. SJ (2009), Psychologia religii, Kraków: Wydawnictwo WAM.

Hough R. (2014), Traits of Chris McCandless, https://prezi.com/yaad9r18mra4/traits-of-chris-mccandless (dostęp: 26.05.2017).

Johnston R.K. (2006), Reel Spirituality (Engaging Culture): Theology and Film in Dialogue, Grand Rapids, Michigan: Baker Academic.

Johnston R.K. (2011), Straight Talk About Families, www.brehmcenter.com/initiatives/reelspirituality/film/articles/straight_talk_about_families (dostęp: 26.05.2016).

Każdy ma swoją Zielona Milę, www.filmweb.pl/reviews/Ka\%C5\%BCdy+ma+swoj\%C4\%85+Zielo n\%C4\%85+Mil\%C4\%99-3797 (dostęp: 01.05.2016).

Kłoczowski J.A. (2006), Czym jest duchowość? Kontekst religijny i historyczny, [w:] A. Grzegorczyk, J. Sójka, R. Koschany (red.), Fenomen duchowości, Poznań: Wydawnictwo UAM. 
Konefał S.J., Kornacki K., Zelent M. (red.) (2013), Sacrum w kinie dekadę później, Gdańsk: Wydawnictwo Uniwersytetu Gdańskiego.

Krakauer J. (1996), Into The Wild, New York: Villard Books.

Laurent S. (2003), The Green Mile: Revisiting the Life and Death of Jesus, www.boheme-magazine. net/sep03/books.html (dostęp: 24.05.2016).

Machoń H. (2009), Wprowadzenie. Religijność między idealizacją a patologizacja, [w:] B. Grom SJ (red.), Psychologia religii, Kraków: Wydawnictwo WAM.

Matti N. (2012), Shi'i Islam in Iranian Cinema: Religion and Spirituality in Film by Nacim PakShiraz, "Journal of Shi's Islamic Studies", No. 5(3).

Pasek Z. (2008), Od religijności do duchowości. Przyczynek do przemian kultury współczesnej, [w:] I. Fiut (red.), Filozoficzne i kulturoznawcze rozważania o duchowości i komunikowaniu, Kraków: AGH, Uczelniane Wydawnictwa Naukowo-Dydaktyczne.

Przylipiak M., Kornacki K. (red.) (2002), Poszukiwanie i degradowanie sacrum w kinie, Gdańsk: Wydawnictwo Uniwersytetu Gdańskiego.

Rossister G. (1999), The Shaping Influence of Film and Television on the Spirituality and Identity of Children and Adolescents: An educational response - Part 3, "International Journal of Children's Spirituality", No. 4(2).

ScottA.O. (2007), Into the Wild - Movie Review. The New York Times, www.nytimes.com/2007/09/21/ movies/21wild.html (dostęp: 01.05.2016).

Socha P.M. (2000), Teolog jako psycholog. Koncepcja rozwoju wiary Jamesa W. Fowlera, [w:] P.M. Socha (red.), Duchowy rozwój człowieka, Kraków: Wydawnictwo Uniwersytetu Jagiellońskiego.

Socha P.M. (2001), Duchowość jako signum temporis. Zastosowanie rozmytego pojęcia do psychologii religii, „NOMOS. Kwartalnik Religioznawczy”, nr 34/36.

Socha P.M. (2014), Przemiana duchowa jako kluczowe pojęcie psychologii rozwoju człowieka, „Psychologia Rozwojowa”, nr 19(3), DOI: http://10.4467/20843879PR.14.015.2302.

Straś-Romanowska M. (2011), Życie duchowe człowieka - niewygodny temat psychologii, [w:] C.W. Domański, T. Rzepa (red.), Na drogach i bezdrożach historii psychologii, Lublin: Wydawnictwo UMCS.

Szymołon J. (2006), Przedmiot psychologii religii, [w:] R.M. Socha (red.), Podstawowe zagadnienia psychologii religii, Kraków: Wydawnictwo WAM.

Waligórska-Olejniczak B. (2013), Sacrum $w$ drodze. Moska-Pietuszki W. Jerofiejewa i Pulp Fiction Quentina Tarantino w kluczu montażowego czytania, Poznań: Wydawnictwo Naukowe UAM.

Wojciechowski P. (2015), Za co Bóg kocha Amerykę? Recenzja kinowa Prosta Historia, www.filmweb.pl/reviews/Za+co+B\%C3\%B3g+kocha+Ameryk\%C4\%99-14 (dostęp: 01.05.2016).

Wojtasik K. (2006), Wiara, [w:] P.M. Socha (red.), Podstawowe zagadnienia psychologii religii, Kraków: Wydawnictwo WAM. 


\section{SUMMARY}

The article attempts to show various ways of presenting spirituality in film. The paper contains a review of selected theories concerning the construct of spirituality in psychology. The main part of the article is comprised of the analysis of spirituality in three American films (The Green Mile, The Straight Story and Into the Wild), each offering a bit different understanding of this notion. The Green Mile refers to universal problems of existence and the spirituality is shown in the direct form of the interventions of supernatural power. The Straight Story speaks of spirituality by telling a "straight" story of an elderly man who fights with his flaws and past failures which allows him to redefine his own identity. Into the Wild, which is also based on a true story, presents a rebellion against the materialism and consumerism of the contemporary world, and a travel which takes place both in physical and spiritual dimensions. The article contains also the analysis of spiritual transformations of the particular film characters.

Keywords: spirituality; psychology; film; spiritual transformation 